NIETZSCHE'S GENEALOGY 



\section{NIETZSCHE'S GENEALOGY}

NIHILISM AND THE WILL TO KNOWLEDGE

R A N D A L L HAVA S

C O R N E L L U N I VERS I T Y PRES S

I T H ACA A N D L O N D O N 


\section{Copyright (C) 1995 by Cornell University}

All rights reserved. Except for brief quotations in a review, this book, or parts thereof, must not be reproduced in any form without permission in writing from the publisher. For information, address Cornell University Press, Sage House, 512 East State Street, Ithaca, New York 14850.

First published 1995 by Cornell University Press.

Printed in the United States of America

(2) The paper in this book meets the minimum requirements of the American National Standard for Information Sciences-

Permanence of Paper for Printed Library Materials, ANSI Z39.48-1984.

\section{Library of Congress Cataloging-in-Publication Data}

Havas, Randall, 1957-

Nietzsche's genealogy : nihilism and the will to knowledge / Randall Havas.

p. $\mathrm{cm}$.

Includes bibliographical references and index.

ISBN 0-8014-2962-5 (cloth : alk. paper)

1. Nietzsche, Friedrich Wilhelm, 1844-1900. 2. Truth. I. Title. B3318.T78H38 1995

193 - dc20 
For my father 
